\title{
Introductory article
}

\section{Assessing Gender mainstreaming in the education sector: depoliticised technique or a step towards women's rights and gender equality?}

\author{
Elaine Unterhalter \& Amy North
}

In 1995 the Beijing Conference on Women identified gender mainstreaming as a key area for action. Policies to effect gender mainstreaming have since been widely adopted. This special issue of Compare looks at research on how gender mainstreaming has been used in government education departments, schools, higher education institutions, international agencies and NGOs . ${ }^{1}$ In this introduction we first provide a brief history of the emergence of gender mainstreaming and review changing definitions of the term. In the process we outline some policy initiatives that have attempted to mainstream gender and consider some difficulties with putting ideas into practice, particularly the tensions between a technical and transformative interpretations. Much of the literature about experiences with gender mainstreaming tends to look at organizational processes and not any specificities of a particular social sector. However, in our second section, we are concerned to explore whether institutional forms and particular actions associated with education give gender mainstreaming in education sites some distinctive features. In our last section we consider some of the debates about global and local negotiations in discussions of gender policy and education and the light this throws on gender mainstreaming. In so doing, we place the articles that follow in relation to contestations over ownership, political economy, the form and content of education practice and the social complexity of gender equality .

\section{Gender mainstreaming: History and definitions}

The term gender mainstreaming emerged in the 1980s and was associated with the campaigning work of women's groups during the UN Decade for Women (1976-1985). The key idea was that women's needs and interests were generally overlooked or made marginal in the development of economic and social policy, and that clear institutional strategies were needed to bring a realisation of gender equality into the mainstream of social development, decision-making, and grass roots work. During the 1980s Ministries of Women and specialist women's units within departments had been established, but the consensus was that these were under-staffed, under-resourced, and generally overlooked when key decisions were taken; they were neither equipped nor expected to take on crucial tasks of implementation (Rai 1997). Gender mainstreaming was advocated as an organisational strategy that would prevent the neglect, or side-streaming, of women's issues and ensure these became the concern of whole organisations, which would structure their major goals around gender equality ( Rai, 2008). However, early commentary in a key work by Jahan (1995), contrasted what she called 'integrationist' approaches to gender mainstreaming, in which gender or women's issues were just 'add ons' to existing policy, and agenda setting approaches in which ideas about gender and women's rights shaped a comprehensive policy orientation.

In 1995 the World Conference on Women, which took place in Beijing, agreed a wide-ranging Platform for Action on women's rights and gender equality. Strategic Objective 8 concerned

\footnotetext{
${ }^{1}$ A number of papers were first presented at the symposium on gender mainstreaming organised by Amy North at the UKFIET Oxford conference in September 2009. For a full list of all papers presented in that symposium, not all of which were revised for this special issue, please see http://www.cfbt.com/ukfiet
} 
institutional mechanisms to be used for the advancement of women. Governments were enjoined to focus on three areas: i) the creation or strengthening of national machineries and other governmental bodies for the advancement of women, ii) the integration of gender perspectives into legislation, public policies, programmes and projects, and iii) the generation and dissemination of gender-disaggregated data and information for planning and evaluation (United Nations, 1995). In this articulation gender mainstreaming is clearly associated with institutional forms, notably bureaucracies, legislation, policy, implementation, and the use of information for evaluation. This meaning of gender mainstreaming evokes both Jahan's integrationist and agenda setting approaches. Women's concerns are to be included in to the work of government through the establishment of specialist bodies and the collection of data on women in national statistics. 'Agenda setting' work is also recommended through the development of gender perspectives in legislation, policy and programmes. However, as we discuss below, some of the debates about gender mainstreaming as an idea and a practice questioned its capacity to bring about institutional change and particularly its capacity to develop an agenda setting approach when other aspects of gendered inequity associated with political economy and socio-cultural formation remained unchanged. The small gains of integrationism and 'adding in' women were often unable to compensate for the difficulties in achieving substantive strategic advances towards agenda setting in policy and practice.

The Beijing Platform for Action outlines many areas of social action to support the advancement of women. The document thus does not give gender mainstreaming, and the work of the institutions of the state, any overarching or lynchpin significance. However, in the decades after Beijing, as a number of the strategic objectives became difficult to achieve (eg. Pearson and Jackson, 1998; Molyneux and Razavi, 2002; Devenish and Skinner, 2006), gender mainstreaming was often identified as an area in which women and gender activists with access to the state or large NGOs could make significant advances (Macdonald, Sprenger and Dubel, 1997; Miller and Ravazi, 1998; Rai, 2003).

To give effect to the actions identified in the Beijing Platform of Action a number of definitions of gender mainstreaming developed. An often quoted definition, adopted by the Economic and Social Council of the UN shortly after the Beijing conference, outlined gender mainstreaming as

"...the process of assessing the implications for women and men of any planned action, including legislation, policies or programmes, in all areas and at all levels. It is a strategy for making women's as well as men's concerns and experiences an integral dimension of the design, implementation, monitoring and evaluation of policies and programmes in all political, economic and societal spheres so that women and men benefit equally and inequality is not perpetuated. The ultimate goal is to achieve gender equality"(UN ECOSOC 1997, p. 28).

The emphasis here is on rationally organized cycles of work within institutions. This was to be an area of much critical comment, which pointed out that the sexism of institutional cultures was as much covert, as overt and that gender machineries, or integrating a gender perspective into policies or information was necessary but not sufficient to change this (Goetz, 1997; Rai, 2003). A number of ironic articles identified the mainstream within organizations as not particularly responsive to gender equality concerns because the mainstream legitimated and routinised practices associated 
with men and masculinity and could be more appropriately termed a 'malestream' (Alvesson and Billing, 2009; Skard, 2009)

In an attempt to take account of how difficult it was to change organizations, later definitions of gender mainstreaming within UN organizations became as much concerned with diffuse attitudes as with planning rounds. Hence UNESCO defined gender mainstreaming in 2003 as

"Mainstreaming" is a process rather than a goal that consists in bringing what can be seen as marginal into the core business and main decision making process of an organization (UNESCO, 2003)

This definition acknowledges that gender mainstreaming is not just a matter of identifying and including particular actions regarding women and men within planning cycles. It entails confronting some of the assumptions of what makes some interests and issues marginal, and acknowledging that these categorisations are often themselves the outcome of gender assumptions. In 2009 the WHO went even further and stressed mainstreaming as primarily associated with attitudes. Institutions bore responsibility for helping to form these

The process of creating this knowledge and awareness of - and responsibility for - gender among all health professionals is called "gender mainstreaming" (WHO, 2009, 74)

These shifts in ideas about the definitions of gender mainstreaming in some ways reflect emerging conclusions from feminist scholarship concerning how gender inequalities came to be reproduced. In its 1997 expression gender mainstreaming is presented as a technical calculation that can be made at every stage of the cycle of devising, implementing and evaluating policy, so that 'women and men benefit equally' and that 'inequality is not perpetuated'. The assumption here is that gender inequality is irrational and associated with a bygone age of discrimination against women. Clear, rational planning for equal allocations can confront the irrationalities of the past. However, as much of the debate on gender equality has made clear (Okin, 1989; Fraser, 1997; Nnaemkea, 2004; Young, 2002; Connell, 2009), for social policy to effect redress the process has to confront deeply entrenched historical inequalities. These are located as much in public institutions as within families, the fabric of cultural and social exchanges and much taken-for-granted everyday practice. In addition gender, race and class and other social divisions and identities shape each other and intersect in complex ways. Failing to acknowledge this might mean achieving equality in one domain but leaving in place grave injustices in another. Thus effecting equal treatment for women and men is not simply a straightforward question of distributing equal amounts of pay or expenditure on schooling, but it entails understanding, for example, that many women do not work in the formal sector, and that relationships of care within families affect how people engage with public institutions. Confronting the marginalization or trivialization of matters concerning gender or women's interest means organizations may need to look beneath processes that assure a surface equality, but in fact maintain deeply entrenched misogynist ideas. This is acknowledged in the later definitions of gender mainstreaming by UNESCO and WHO, which place much stress on changing knowledge, awareness and attitudes in the hope that it is these that will change institutions. This is a reversal of the earlier view of gender mainstreaming that was often interpreted in the form that it was what institutions did, either in integrationist or agenda setting guise, that would change actions. 
The problematic associated with these definitions has been examined in much of the literature on gender mainstreaming (eg Goetz, 1997; Rai, 2003; Squires, 2005). This has considered the extent to which gendered state processes can be changed through the techniques of gender mainstreaming and whether gender mainstreaming has been responsible for a co-optation of feminism, limiting its transformatory politics. A persistent question is how, in assessing the usefulness of gender mainstreaming, one takes account of the complexity of local contexts. Many of the papers in this special issue consider aspects of these critiques in reflecting on data collected from educational settings. Before commenting on the issues they raise, we outline some examples of the adoption of gender mainstreaming, highlighting how widespread it has become in the social policy of supranational bodies and governments.

In 1995 the Council of Europe's Steering Committee on Equality between Women and Men established an expert group on gender mainstreaming. Its recommendations, published in 1998, were translated into a wide range of European languages, and the Committee of Ministers, made up of European foreign ministers, recommended that gender mainstreaming should be adopted into the work of all other inter-ministerial committees, although take up was subsequently slow (Verloo, 2005,349-350). In 199821 countries had 'high level' mechanism's for gender mainstreaming, that is either stand alone Women's Ministries commissions or offices located in a Cabinet or Prime Minister's Office, while 20 had 'low level' mechanisms taking the form of a women's bureau, or a division for women or gender within a particular Ministry (True \& Mintrom, 2001. 31-32). In both categories were countries from the global north and south. In 1999 the Treaty of Amsterdam came into force which placed a binding responsibility on all European Union governments to undertake 'active gender equality' policies making use of gender mainstreaming. Articles 2 and 3 of the Treaty made equal opportunities for women and men, not just equal pay or equal treatment at work, a central objective of the European Union, requiring the organisation strive to incorporate this into all policies. While these articles did not create legally enforceable rights for European women, they did represent a political commitment to gender mainstreaming, which gender advocates made use of in a variety of ways(Mazey, 2002).

The formation of the African Union in 2002 was accompanied by a high level emphasis on gender mainstreaming which found policy expression in The 2003 Maputo Protocol to the African Charter on Human and People's Rights on the Rights of Women in Africa. This came into force in 2005, having been ratified by 15 countries. By December 200945 of the 53 countries of the African Union had signed the Protocol, while 27, located in all regions of Africa, had ratified it, indicating a commitment to implement its provisions within domestic legislation. The Protocol contains an extensive statement of gender mainstreaming including commitments to Constitutional and legal reforms to ensure equality between women and men. It articulates far-reaching goals to protect women's rights, including action to eliminate violence against women, protect women's property rights, outlaw marriage under 18 and 'integrate gender sensitisation and human rights education' at all levels of the education system (African Union, 2003)

In 2003 UNESCO published a five year medium term strategy stating that :

a gender perspective will be integrated in policy planning, programming, implementation and evaluation activities in all areas of UNESCO's competence with a view to promoting empowerment and achieving gender equality. Women's priorities and vision of development goals and approaches will be addressed and promoted through greater participation of women at all levels and in all areas of UNESCO's action (UNESCO, 2003. 2) 
The rationale for mainstreaming gender was partly animated by concern to keep faith with the commitments made at Beijing

[we need] ..to deliver a clear message to governments reminding them of their obligation o honour the Beijing commitments(UNESCO, 2003,6) .

The statement was also linked to a view that gender equality was integral to UNESCO's vision of equitable and sustainable development:

As long as both women's and men's priorities and visions of development goals are not clearly addressed, taken into account and promoted, not only are we excluding half of humanity, we are jeopardising our prospects at achieving sustainable development. (UNESCO, 2003, 6)

The strategy proposed established the need to go beyond particular programmes directed to women or men .
A profound transformation of the structures and systems, which lie at the root of subordination and gender inequality, is required. To do this, we must uncover the hidden biases that limit women's and men's ability to enjoy equal rights and opportunities and find the most effective and culturally appropriate means to support women's and men's capacities to drive social change. For UNESCO this means that we must mainstream gender concerns in all our operations (UNESCO, 2003, 6)

This transformative vision for gender mainstreaming echoes that of the African Charter. The approach is about transforming institutions and through this undoing 'structures and systems' which constitute and reproduce inequality.

UNESCO's vision for gender mainstreaming is somewhat different from that of the World Bank, which has seen the practice in more minimalist terms. For the Bank gender mainstreaming is, for example, a key platform for effective poverty reduction because "[there is] evidence that gender plays an important role in determining economic growth, poverty reduction, and development effectiveness"(World Bank 2002, 1). The stress here is on gender mainstreaming as a technique to make particular forms of poverty reduction efficient, while the emphasis in the African Charter and the UNESCO strategy is for a wider vision of the intrinsic value of gender equality and the complex processes entailed in developing institutions and actions to support this. This tension with regard to whether gender mainstreaming is to be seen as a technical exercise to secure other ends, or as part of a transformatory process to realise values associated with gender equity and equality, is evident in many education settings, as a number of the articles in this issue show.

\section{Some accounts of gender mainstreaming in practice}

Many countries and multilateral organizations have used gender mainstreaming in social policy. Experiences highlight the complexity of trying to effect change in an area which encompasses so wide a range of social and institutional relationships spanning international and national contexts. We select two instances from a large literature to indicate both the complexity of multiple sites of engagement and the salience of local political contexts. These indicate that simple assessments of the effectiveness of gender mainstreaming may overlook some of the particularly interesting aspects of implementation associated with political and socio-cultural alignments both within and across national contexts .

Indonesia adopted gender mainstreaming in 1997-8 as part of a Poverty Reduction Strategy Programme (PRSP) imposed by the IMF and World Bank after the Asian economic crisis had left the country with a $13 \%$ reduction in GDP, rising levels of poverty and debt (Schech and Mustafa, 2010). 
Complex political alignments associated with heightened support for democratization, the emergence of women's groups, debates over Islamic identity and the ways in which links with international institutions like the IMF were tainted by the failures of the previous regime, meant that a 'technical' PRSP, with inadequate attention to gender and poverty, could not be simply imposed on the country. While the government was not able to ensure the PRSP process had completely adequate gender representation or expertise, and gender disaggregated data was not fully available, crucial alliances were formed between individual government officials involved with the PRSP, gender NGOs and university-based gender experts. This alliance gradually established a presence in the policymaking process and their work resulted in a more robust strategy on gender and poverty than might have been anticipated (Schech and Mustafa, 2010). While this policy still remains to be evaluated in terms of action, Schech and Mustafa suggest gender mainstreaming can be understood in terms of complex alliances and power play and these political shifts may be of considerable significance for later developments, even if a technical institutional form of mainstreaming may not be evident.

Similar conclusions have been drawn from assessments of DFID's experience with gender mainstreaming. DFID initiated work on gender equality in the 1980s and the extent of this increased after the Beijing Conference in 1995, culminating in the adoption of a "twin track" strategy which sought to combine specific work on women's empowerment with a commitment to mainstream gender throughout its development programmes (Jensen et al 2006, Watkins 2004). The core elements of this strategy for work on gender were set out in the paper 'Poverty Elimination and the Empowerment of Women', published in 2000 (DFID 2000). In 2007, DFID launched a 'Gender Equality Action Plan', setting out how it planned to use resources, partnerships with others, staff management and planning processes to improve its impact on gender equality and women's empowerment (DFID 2007). Particular importance was given to the need to strengthen partnerships with others - including national governments, multi-lateral agencies, and civil society - on gender equality, and to increase internal expertise and capacity on gender. The plan draws on the results of a number of evaluations and critical appraisals of DFID's work on gender which were carried out between 2000 and 2007 (MacDonald 2003, Watkins 2004, Jensen et al 2006). These evaluations, while positive about the strong commitment that DFID has shown to gender equality at the policy and strategy level, suggest that there may have been problems of "policy evaporation", and a failure to consistently translate this commitment into practice. Jensen et al (2006) note that, despite recognition of the links between gender equality and poverty reduction in policy, rather than being integral to all programming, gender activities have often been "pursued in isolation, as an add-on". They point to internal problems of uneven leadership across the organisation; a lack of strong incentives to work on gender; and the need to invest in staff and other resources, especially at country level in order to advance work on gender more effectively. However, there are additional difficulties also linked to the particular aid and global policy environment in which DFID operates. Jensen et al (2006) point, to the impact that new aid modalities, such as direct budget support and sector wide approaches, and the move to greater country ownership of development plans have had on gender equality programming. In some countries, such as Kenya, limited institutional space to take forward policy commitments to gender equality mean that these have fallen off the agenda or are only accomplished in the context of policy declarations linked to aid (Unterhalter et al 2009). Meanwhile, the focus on the MDGs since 2000 mean that , whilst there has been attention to issues of gender equality in some areas (notably education and health), gender work in other areas, such as economic development, tends to be neglected (Jensen et al 2006; Watkins 2004).

To some extent DFID's attempts to mainstream gender reveal a tension between different approaches to gender. In 2003 the assessment of DFID's work on gender produced by the civil society Gender and Development Network noted that their policy documents "vacillate between a rights-based approach to gender equality and one based on efficiency," (MacDonald, 2003; p6 ). The 
2007 Action Plan continues to contain elements of both approaches, emphasising both the intrinsic importance of gender equality and women's rights as transformative and linking gender equality instrumentally to economic growth.

Both the example from Indonesia and from the work of DFID highlight how easy it was for gender mainstreaming to slip from an agenda setting aspiration to a side-stream, characterised by neglect, minimal action or technical support to other development goals. Both, however, also highlight the significance of the presence of gender activists inside or with access to powerful bureaucracies. In addition both draw out the way in which aspects of global political economy have significant bearing on what may or may not be achieved through gender mainstreaming.

\section{Political strategies for addressing gender: Debating assumptions}

The prominence given to gender mainstreaming as a policy idea has been matched by a critical literature regarding its assumptions. This has often been conducted as a dialogue between reflections on theory and analyses of practice. Judith Squires (1999) identified a number of political strategies for engaging with gender. She termed these inclusion, reversal and displacement. Inclusion is the process of focussing on the exclusion of women from, for example certain levels of education or studying particular subject areas. Reversal problematizes particular masculinised cultures or processes in organizations, for example long working days or acceptance of sexual harassment. Displacement, sought to 'go beyond gender' and expose the ways in which assumptions about gender identities and practices, for example women's 'special' capacity to teach very young children were themselves the outcomes of particular constructions of the social world. Squires (2005) assessed different strategies in gender mainstreaming in relation to these different perspectives on gender. In the process she and others (Verloo, 2005, 347; Walby, 2005a; 2005b ) criticised Jahan's (1995) distinction between agenda setting and integrationist approaches to gender mainstreaming for its failure to expand the notion of agenda setting beyond the inclusion of women in decision-making, and the lack of consideration given to which women's voices should be included to help formulate a non-hegemonic politics. Booth and Bennett (2002) simultaneously distinguish and connect three strands within gender mainstreaming. These are firstly a focus on the equal treatment of women and men which works to provide equal rights and opportunities. Secondly, a valuing of women's perspectives, which requires policies concerned to achieve equality of outcome. Given women's historic experience of discrimination and disadvantage, this requires policy that accommodates forms of redress. Thirdly, they highlight the importance of identifying a gender perspective, which values difference and 'aims to transform the organization of society to a fairer distribution of human responsibilities' acknowledging that men can also be disempowered by existing social arrangements (Booth and Bennett 2002, 434). Verloo (2005) asked whether gender mainstreaming could include a flexible, operational goal that would allow it to work as a form of what Squires had termed displacement, allowing institutions to problematise the very binaries of gender formations.

It can be seen that this critical conceptual literature has tended to focus on where to place gender mainstreaming in relation to a broader feminist project regarding how to understand gender and act to change injustice and subordination. This approach has been less concerned with the demands and contexts of delivery than more detailed studies of gender mainstreaming in particular social sectors such as rural development (Walker, 2003 ), social welfare (Hassim, 2005) economic policy (Elson, 2004) or development co-operation (Tiessen, 2007). However, the case studies contained in Lombardo, Meier and Verloo (2009) on gender equality as an elastic idea show how a discursive politics around meanings of gender equality leads to processes that reduce the transformatory potential of the term, with particular consequences for action. It is thus clear that a lively debate 
about what addressing gender inequality and inequities mean is being conducted both at the level of conceptualization and through reflection on the politics of implementation.

This work suggests that within the education sector we should expect to find similar trends, where complex local conditions and the exigencies of practice will affect the implementation of gender mainstreaming. This will be evident both in negotiations over meaning and action. However there are also questions as to whether gender mainstreaming in education might have some additional particular features which raise additional questions not so evident in other sites of policy enactment.

\section{Is gender mainstreaming in education distincitve?}

Education is often regarded as a distinctive space for social development, as it combines both a means to effecting gains in, for example the development of human capital or enhanced health, and an end in itself. Thus education may be seen as a technical and instrumental set of relationships to achieve particular aims of economic growth or reduced fertility, or may be viewed as intrinsically worthwhile in itself, whether or not these aims are achieved. Despite a wide literature on how education both reproduces and transforms social stratification and gender divisions (eg. Carnoy, 1974; Bourdieu, 1973; Apple, 1982; Aikman \& Unterhalter, 2005; Stromquist 2006), a number of authors comment on education as an indeterminate space entailing identities, social structures and relations, the texture of particular formations on epistemology and ontology (eg Unterhalter, 1999a; Morrell et al 2009; Bullen \& Kenway, 2005 ). Education is thus a site of practice and experience which has the potential to be much more self-reflective than might be the case in the delivery of health services or agricultural policy, because of the explicit discussion of values in relation to much education work. However, reform in education has sometimes been reduced to little more than techniques for improving test scores, increasing the recruitment of teachers from particular groups or with certain skills, or enhancing local efficiency through decentralization. This concern with advancing the education of girls because it is a feature of 'what works' for social stability or human capital development (Unterhalter, 2000) would tend to privilege a meaning of gender mainstreaming concerned with a particular set of techniques to increase gender parity in enrolments or the numbers of women teachers. But stress on 'what works 'to achieve limited goals in gender equality stands in contrast to discussions about gender equality, and hence gender mainstreaming, as something which 'matters' because it expresses particularly important social values. (Unterhalter, 2009). An aspect of the distinctive space of education is that it addresses questions of 'what works', 'what matters' and how we think about their relationship (ibid).

McCowan,(2009)in writing about schools as sites to advance ideas about citizenship and human rights, has developed the concept of seamless enactment to express both the potential of ideas about equality moving from theory to practice, and the disjunctures that might emerge. It might be that this is a rich seam of inquiry to pursue in relation to gender mainstreaming in education as it tries to capture both aspects of the general space of putting policy into practice and some of the specific features of education as a site where learning and teaching about gender and its contested meanings and values takes place.

A range of different meanings of gender and equality at play in global social justice initiatives concerning gender equality and education have been outlined (Unterhalter, 2007). At one end of a continuum the idea that gender is about counting the numbers of girls in school or women teachers 
can be seen to chime well with Jahan's (1995) notion of integration and Squire's (2005) identification of inclusion as a particular form of gender mainstreaming. Unterhalter's identification of a separate stream of work on gender equality in education that tackles and attempts to transform gendered power structures in relation to curriculum, distribution of resources or concern with gender based violence resonates with Squires' notion of feminist strategies of reversal. This task seem particularly challenging, although a number of the articles in this special issue report on attempts to implement this. The third meaning Unterhalter identifies for work on gender in education engages with issues of identification, agency and diversity. This appears the most diffuse and least amenable to formalization through institutional change. Although arguably without changes in institutional culture and the forms of identification associated with this it is difficult to sustain and support different enactments of gender equality (see Morrell et al, 2009).Subrahmanian (2007a; 2007b), in her discussion of gender mainstreaming in education, has suggested scaling down expectations and understanding gender mainstreaming in terms of different fields, for example policies, institutional change, politics, advocacy and resource distribution. This suggests possibly working on each of the different meanings of gender equality and education Unterhalter identifies though somewhat separate strategies. However, McCowan's approach also enjoins giving particular attention to pedagogies. This entails thinking about gender, equity and equality in relation to questions of learning and teaching as well as policy enactment. It is clear that without some attention to questions of content, not just form or institutional process, distinctive features of the experience and practice of gender mainstreaming in education may be lost.

The articles in this special issue document different sites of work on gender mainstreaming in education: education Ministries and Departments, large NGOs, multilateral organizations and universities. The question of pedagogy and ideas about gender equality is highlighted in some initiatives and omitted in others. The reasons for this are partly an outcome of complex global, national and local negotiations over gender mainstreaming. It is these relationships, which highlight the question of ownership and meaning, that require particular careful attention in order to understand how and why education might provide additional and different insights into the practice of gender mainstreaming to other areas of policy delivery and social development.

\section{Global, national and local negotiations over gender mainstreaming in education}

As the history of gender mainstreaming since the 1980 s indicates, it was an idea developed at a global and national level and then re-articulated in many different institutional and organizational sites. It has therefore been much studied as an instance of state feminism and the transfer of ideas between global and local centres (Mazur \& McBride, 2007;Subrhamanian, 2007a). In this it shares a number of features with other initiatives to advance a particular gender agenda in education. The Compare special issue on Gendered Education and National Development (Vol 38, No 5, 2008) contained articles which highlighted the work of Northern development co-operation agencies and research agendas advancing particular concerns with gender, and eliciting complex local engagements (eg.Fennell and Arnot, 2008a; Greany, 2008). This theme is examined in a number of works on global gender and education policy (eg Lind, 2006; Fennell and Arnot, 2008b). Thus studies of gender mainstreaming in education sites, which highlight contestations over form, content, and ownership, are familiar from some other studies. All these works illuminate how contextual questions relating to political economy and the social complexity of gender equality in education have considerable significance in understanding how gender mainstreaming has been enacted in 
particular education settings. But the general literature on global gender policy agendas and local responses often does not bring out the self critical reflexivity and concern with pedagogy, experience and practice, which is evident in some of the work on gender mainstreaming and education in this special issue and which may be an important theme as further studies in this area emerge.

Introducing the articles: Negotiating meaning, context, and the potential of education

A number of the articles in this issue are concerned with different emphases of meaning given to gender across global and national sites of engagement. The articles by Rosie Peppin Vaughan and Amy North both reveal the way in which different approaches to gender have played out in international organisations concerned with education. They highlight the tensions and negotiations between a view of gender as transformative and political, or as technical and instrumental to tackle problems of economic growth. Peppin Vaughan takes a historical look at shifting approaches to girls' education within the work of the World Bank and UNESCO between 1945, and 2000. She explores the way in which UNESCO's is negotiated across governments and civil society, often resulting in "consensual policy" in which there is no strong orientation to any particular approach, in contrast to the World Bank where a strongly instrumental approach based on arguments linking female education to growth and efficiency has been dominant. Amy North examines the way in which international organisations - including international NGOs as well as donors and UN agencies - have drawn on international policy frameworks, in particular the MDGs, to advance aspects of gender equality within their education work. She argues that the MDG framework has encouraged a focus on gender parity - equal numbers of boys and girls in schools. However it has not facilitated discussions around more substantive notions of equality linked to ideas around empowerment and transformation within organisations.

Other articles bring out the challenge of engaging with some of the questions of pedagogy and specific education experiences. Shirley Miske, Margaret Meagher and Joan DeJaeghere focus on the work on one organisation - CARE USA - and are concerned with the way in which approaches to gender mainstreaming are used at the level of operations, that is specific activities 'on the ground'. Their article considers the use of a specially developed framework for gender analysis in education the comprehensive Common Indicator Framework (CIF), which integrates dimensions concerned with educational quality and attainment, equality and empowerment. Drawing on data from programmes in Mali and Cambodia which use the CIF they argue for the need for actions concerned with gender to base interventions on a deeper understanding of girls' and boys' perceptions of empowerment and equality. In their work they thus highlight how analysis and action in particular locations help take gender mainstreaming from policy to practice. They also suggest a particular form of practice might help engagement with distributing equal amounts of teaching or regard to women and men, and with confronting some of the taken-for-granted ideas about gender which make transformation difficult. However, evaluations will be needed over a number of years to assess the effects of these initiatives.

Oluwafunmilayo Para-Mallam's article also looks at some of the distinctive features of education sites and gender inequality. In looking at gender equality in the Nigerian context she points to the critical role that religious and cultural traditions may play in perpetuating particular forms of gender relations. The article explores how, despite the existence of national policies focused on improving 
girls' enrolment and mainstreaming gender perspectives within the education sector, pervasive cultural and religious bias means that gender inequalities persist. It argues for the need to go beyond technical measures to get girls in school, and to engage critically with sexist interpretations of religious texts and cultural norms, to transform patriarchal education systems. The analysis thus confirms for the education sector a number of studies of gender mainstreaming in other areas of social development (Rai, 2008; Verloo,2005; Goetz 1997) which highlight how institutional change does not happen independent of other shifts in gendered social relations. Gender mainstreaming may be necessary but not sufficient to challenge deeply held forms of discrimination.

The importance of context, and of engaging with local understandings of gender is also central to Ann-Louise Silfver's critical examination of the way in which conceptions of gender equality and gender mainstreaming, rooted in gender equality politics in Sweden, have been received, by education officials in Lao People's Democratic Republic. Her article considers the way in which Lao education officials, working with development cooperation partners, negotiate local gender issues in response to gender mainstreaming policies associated with aid relationships. She suggests that the nature of donor-driven development cooperation means that gender mainstreaming is often reduced to technical process involving counting numbers, with little room for local interpretations. In her critique of this practice she argues for the need to pay closer attention to the specific historical and political contexts in which gender equity politics and mainstreaming policies are developed and the implications of this for the way in which they are translated across contexts. The politics of gender in Lao PDR is associated with a particular history of political mobilisation and affiliation. Mainstreaming without a knowledge of these relationships does not engage with the complexity which characterises this context. This work thus exemplifies the self-critical reflexive turn that has been a feature of a number of studies of gender mainstreaming, setting it somewhat apart from the literature of interpreting global gender policies in local contexts.

Jenni Karlsson's analysis of gender mainstreaming in a South African provincial education department also highlights the complexities of carrying out gender mainstreaming in local contexts. Her article points to how difficult it is for local education officials to institutionalise a concern with promoting gender equality in their work, when only some pieces of a supporting framework are in place. Despite attempts to implement both technical and transformative approaches to mainstreaming gender, lack of resources has made it difficult to move beyond small-scale, "topdown" interventions and build commitment of institutionalise practice at district levels. This study, like Para-Mallam and Silfver's, suggests that particular forms of gender mainstreaming might be being established in national and provincial education ministries, but that giving these institutions substance and relating them to the specific gender and education histories of particular contexts remains an immense challenge, made all the more daunting because there are often few advocates of a gender approach, and these are all too frequently seen as outsiders, linked with donor relationships or different values.

Both Louise Morley and Rosalind Pritchard explore approaches to gender within higher education. Rosalind Pritchard's article, which examines the experiences of female academics in British and German higher education, while not explicitly concerned with gender mainstreaming, points to the difficulty of overcoming covert forms of discrimination against women, even where overt gender 
bias has been eliminated. The article points to the way in which women's career progression and experience of life in academia is affected by gendered expectations regarding dress and presentation, and the difficulties of combining an academic career - associated with a culture of working very long hours - with a family. She thus charts how difficult it is to bring about gendered change in the cultures of institutions, even those which are changing and employing more women.

Louise Morley's article, which draws on research conducted as part of the 'Widening Participation in Higher Education in Ghana and Tanzania: Developing an Equity Scorecard', explores how gender mainstreaming has enabled some - mainly younger and socially privileged - women to gain access to particular academic programmes, but has been less successful in challenging discriminatory practices experienced by women within Universities in both countries. The article highlights the difficulties involved in moving beyond simply increasing numbers to disrupt the "cultural scripts and the hegemonic codes of femininity and masculinity that continue to influence subject choice" and to transform the power relationships that enable practices such as the sexual harassment of female students to thrive. It concludes that "GM [gender mainstreaming] requires access to, and control over, material and symbolic resources. It also requires changes in deep-seated values and relationships that are held in place by patriarchal power and privilege." In this it confirms theoretical studies by Squires (2005) and Walby (2005a) and empirical work by, for example Verloo (2005), Lombardo, Meier and Verloo (2009) and Hassim (2009) that gender mainstreaming, which is limited just to inclusion of women into certain spaces cannot go far enough to transform the multiple relationships that sustain gender inequality.

Mainstreaming in education raises questions about the institutional space of the state and the ambiguities of work with civil society and NGOs to promote gender equity. In some of the articles in this special issue it is evident mainstreaming processes entail limited technocratic exercises, a sidestreaming of women's concerns, and a displacement of thinking about empowerment and transformation. Others suggest possibilities for adapting mainstreaming to engage with particular opportunities to effect gendered change in education. It is evident that in different education contexts meanings of gender, mainstreaming, and equality are reinterpreted, negotiated, and contested as they move between global and local spaces. Different types of institutional space, each associated with particular processes of delivery, offer more or less opportunity for transformatory reflection. In some there are possibilities for reflexive consideration of pedagogy and the politics of change, while in others these possibilities are at best truncated and at worst excluded or delegitimized. Gender mainstreaming does not appear in any site of education practice to perform a function as the key to realising the vision of the Beijing Platform of Action. But the articles in this special issue suggest it would be premature to see gender mainstreaming simply as a misguided reform initiative. The questions these analyses of implementing gender mainstreaming in education raise point to the significance of assessing ownership of strategies for change, the importance of investigating the political economy and socio-cultural contexts of institutional shifts, and the form and content of education practice associated with gender justice and rights. Researching the experience with gender mainstreaming in education offers expanded insight into the social complexity of realising widely endorsed aspiration for gender equality in education, and hence may contribute to generating different forms of practice. 
Note:

This article draws on research conducted for the ESRC funded project Gender, education and global poverty reduction initiatives (Award no. RES-167-25-0260). We are grateful to all the members of that research team:(Veerle Dieltiens, Jenni Karlsson, Setungoane Letsasi, Herbert Makinda, Jane Onsongo and Chris Yates) for the discussions over three years of our work together which have informed the analysis we make.

\section{$\underline{\text { References }}$}

African Union, 2003, 'Protocol to the African Charter on Human and Peoples' Rights on the rights of women in Africa' Adopted by the Heads of State of the African Union, Maputo. On line at http://www.achpr.org/english/ info/women en.html (consulted April 2010)

Aikman, S., \& Unterhalter, E. (2005). Beyond access : Transforming policy and practice for gender equality in education. Oxford: Oxfam GB.

Apple, M. W. (ed.) (1982). Cultural and Economic Reproduction in Education: Essays on Class, Ideology and the State. London: Routledge.

Booth, C. and Bennett, C. (2002) Gender Mainstreaming in the European Union: Towards a New Conception and Practice of Equal Opportunities? European Journal of Women's Studies 2002 9(4) 430-446

Bourdieu, P. (1973). 'Cultural reproduction and social reproduction', in Brown, R., (ed.), Knowledge Education and Social Change. London: Tavistock.

Bullen, E., \& Kenway, J. (2005). Bourdieu, subcultural capital and risky girlhood. Theory and Research in Education, 3(1), 47-61.

Carnoy, M. (1974). „Education for Development or Domination? A Theoretical Framework“. In Education as Cultural Imperialism. London: Longman

Connell, R. (2009) Short Introductions: Gender Cambridge: Polity

Devenish, A. \& Skinner, C. (2006) Collective Action for those in the Informal Economy: The Case of the Self Employed Women's Union. In Ballard, R., Habib, A. \& Valodia, I. (Eds.) Voices of Protest: Social Movements in Post-Apartheid South Africa. Durban, University of KwaZulu-Natal Press.

DFID (2000) Poverty Elimination and the Empowerment of Women: Strategies for Achieving the International Development Targets, London: DFID

DFID (2007) Gender Equality Action Plan 2007-2009 Making faster progress to gender equality Retrieved March, 2010, from http://www.dfid.gov.uk/Documents/diversity/gender-equality-plan2007.pdf

Elson, D. (2004) 'Engendering government budgets in the age of globalization' International Feminist Journal of Politics 6.4 
Fennell, S., \& Arnot, M. (2008a). Decentring hegemonic gender theory: The implications for educational research. Compare, 38, 525-538

Fennell, S. \& Arnot, M. (2008b)eds. Gender education and equality in a global context Abingdon: Routledge

Fraser, N. (1997). Justice Interruptus: Critical Reflections on the "Postsocialist" Condition. London: Routledge.

Goetz, A. M. (1997). Getting institutions right for women in development. London: Zed.

Greany, K. (2008). Rhetoric versus reality: Exploring the rights-based approach to girls' education in rural Niger. Compare, 38, 555-568.

Hassim, S. (2005). Turning Gender Rights into Entitlements: Women and Welfare Provision in Postapartheid South Africa. Social Research: An International Quarterly of Social Sciences 72(3), 621646.

Jahan, R. (1995) The elusive agenda: mainstreaming women in development. London: Zed Books.

Jensen, R. et al, COWI Evaluation Team, (2006), Evaluation of DFID's Policy and Practice in Support of Gender Equality and Women's Empowerment, Synthesis Report, Department for International Development (DFID) EV669.

Lind, A. (2006), ' Reflections on mainstreaming gender equality in adult basic education programmes' International Journal of Educational Development Vol 26, 2, 166-176

Lombardo, E., Meier, P and Verloo, M. (2009) The discursive politics of gender equality: Stretching, bending and policy-making. London: Routledge.

MacDonald, M. (2003) 'Gender Equality and Mainstreaming in the Policy and Practice of the UK Department for International Development', London: Womankind

MacDonald, M., Sprenger, E. and Dubel, I. (1997) Gender and Organizational Change: Bridging the Gap between Policy and Practice. Amsterdam: Royal Tropical Institute

Matts, and Billing, Y,D.(2009) Understanding gender and organizations $2^{\text {nd }}$ ed London: Sage

Mazey, S. (2002) 'Gender Mainstreaming Strategies in the E.U.: Delivering on an Agenda?' Feminist Legal Studies 10(3) 227-240

Mazur, A. D. E. McBride. 2007. 'State Feminism Since the 1980's: From Loose Notion to Operationalized Concept.' Politics \& Gender 3(3):501-12

McCowan, T. (2009) Rethinking citizenship education: A curriculum for participatory democracy Continuum, London 
Miller, C. and Razavi, S. (1998) (Eds.) Missionaries and Mandarins: Feminist Engagement with Development Institutions, London: Intermediate Technology

Molyneux, M. and Razavi, S. (Eds.) ( 2002) Gender justice, development and rights Oxford: Oxford University Press

Morrell, R., Epstein, D., Unterhalter, E., Bhana, D., \& Moletsane, R. (2009). Towards Gender Equality: South African schools during the HIV and AIDS epidemic. KwaZulu-Natal: University of KwaZulu-Natal Press.

Nnaemeka, O. (2004). Nego - Feminism: Theorizing, Practicing, and Pruning Africa's Way. Signs: Journal of Women in Culture and Society, 29(2), 357-385.

Okin, S. M. (1989). Justice, gender and the family. New York: Basic Books.

Pearson, R., \& Jackson, C. (Eds.). (1998). Feminst Visions of Development: Gender Analysis and Policy. London: Routledge.

Rai S. M. (1997) 'Crossing boundaries: women's North-South cooperation seminar - a report', Journal of Gender Studies, 6, 63-70.

Rai, S. M. (Ed.). (2003). Mainstreaming Gender, Democratizing the State: International Mechanisms for the Advancement of Women Manchester: Manchester University Press

Rai, S. M. (2008). The Gender Politics of Development: Essays in Hope and Despair. London: Zed Schech, S. and Mustafa, M. (2010) 'The Politics of Gender Mainstreaming Poverty Reduction: An Indonesian Case Study' Social Politics: International Studies in Gender, State \& Society 2010 17(1):111-135

Skard, T. (2009) 'Gender in the Malestream- Acceptance of women and gender equality in different United Nations organizations' Forum for Development Studies, 36, 1, 155-191.

Squires, J. (1999) Gender in political theory Cambridge: Polity

Squires (2005) 'Is Mainstreaming Transformative? Theorizing Mainstreaming in the Context of Diversity and Deliberation' Social Politics: International Studies in Gender, State \& Society 12(3) 366388.

Stromquist, N. P. (2006). Gender, education and the possibility of transformative knowledge. Compare: A journal of comparative education, 26(2), 145-161.

Subrahmanian, R. (2007a). Making sense of gender in shifting institutional contexts: some reflections on gender mainstreaming. In A. Cornwall, E. Harrison \& A. Whitehead (Eds.), Feminisms in development: Contradictions, contestations and challenges (pp. 113-121). London: Zed Books Subrahmanian (2007b). Gender in Primary and Secondary Education: A handbook for policy-makers and other stakeholders. London: Commonwealth Secretariat. 
Tiessen, R. (2007) Everywhere/Nowhere - Gender Mainstreaming in Development

Agencies Bloomfield: Kumarian Press

True, J. and Mintrom, M. (2001). 31-32 'Transnational Networks and Policy Diffusion: The Case of Gender Mainstreaming' International Studies Quarterly, Vol. 45, No. 1 (Mar., 2001), pp. 27-57

UNESCO, 2003, UNESCO's Gender Mainstreaming Implementation Framework 2002-2007. Paris: UNESCO Retrieved March, 2010, from http://unesdoc.unesco.org/images/0013/001318/131854e.pdf

United Nations (1995) Beijing Declaration, Fourth world conference on women Beijing Declaration (1995). Retrieved March, 2010, from http://www.un.org/womenwatch/daw/beijing/platform/declar.htm

United Nations (1997) 'Report of the Economic and Social Council for 1997', A/52/3, 18 September 1997

Unterhalter, E. (1999). 'Citizenship, difference and education - reflections inspired by the South African transition' in Yuval-Davis, N. And Werbner, P. (Eds.) Women, citizenship and difference London: Zed Books

Unterhalter, E (2000) 'Transnational visions of the 1990s. Contrasting views of women, education and citizenship' in Arnot, M. and Dillabough, J.A. eds. Challenging democracy: feminist perspectives on the education of citizens in Arnot, M. and Dillabough, J.A. eds. London: Routledge, pp.87-102

Unterhalter, E. (2007). Gender, schooling and global social justice. London: Routledge

Unterhalter, E. (2009). Translations and transversal dialogues: An examination of mobilities associated with gender, education and global poverty reduction. Comparative Education, 45(3), 329 345.

Unterhalter, E., North, A., Karlsson, J., Onsongo, J., \& Makinda, H. (2009). Four forms of disconnection: Negotiating gender, education and poverty reduction in schools in Kenya and South Africa, Working Paper 1, Gender, education and global poverty reduction Initiatives.

Verloo, M. (2005) 'Displacement and Empowerment: Reflections on the Concept and Practice of the Council of Europe Approach to Gender Mainstreaming and Gender Equality' Social Politics: International Studies in Gender, State \& Society 2005 12(3):344-365

Walby, S. (2005a). Gender Mainstreaming: Productive Tensions in Theory and Practice. Soc Pol, 12(3), 321-343.

Walby, S. (2005b). Introduction: Comparative gender mainstreaming in a global era. International Feminist Journal of Politics, 7, 453-470. 
Walker, C. (2003). Piety in the Sky? Gender Policy and Land Reform in South Africa. In S. Razavi (Ed.), Agrarian Change, Gender and Land Rights. Malden: Blackwell Publishing/UNRISD.

Watkins, F (2004) Evaluation of DFID Development Assistance: Gender Equality and Women's Empowerment -DFID's Experience of Gender Mainstreaming: 1995 to 2004, Glasgow: DFID

WHO, 2009, Women and health Geneva: World Health Organisation

World Bank (2002) 'Integrating Gender into the World Bank's Work: A Strategy for Action', Washington, DC: World Bank

Young, I. M. (2002). Inclusion and Democracy? Oxford: Oxford University Press. 